\title{
Letters
}

\section{Seasonal Patterns in Hydrogen Isotopes of Claws from Breeding Wood- Warblers (Parulidae): Utility for Estimating Migratory Origins}

\section{Variation saisonnière des isotopes d'hydrogène de griffes de parulines (Parulidae) reproductrices : utilité pour évaluer les origines migratoires}

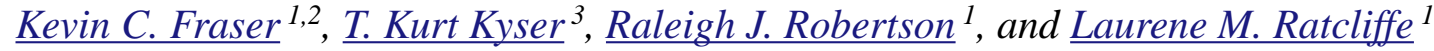

\begin{abstract}
The global decline in many species of migratory birds has focused attention on the extent of migratory connectivity between breeding and wintering populations. Stable-hydrogen isotope $(\delta D)$ analysis of feathers is a useful technique for measuring connectivity, but is constrained by features of molt location and timing. Claws are metabolically inert, keratinous tissues that grow continuously and can be sampled at any point in the annual cycle, thus providing potentially useful clues about an individual's previous movements. However, variation in the rate at which claws incorporate local $\delta \mathrm{D}$ values is not well described. We measured $\delta \mathrm{D}$ values in claws of two species of Neotropical-Nearctic migrant wood-warblers (Goldenwinged Warbler and Cerulean Warbler) breeding in eastern Ontario, Canada to investigate the rate of $\delta \mathrm{D}$ change through the breeding season and the utility of claw $\delta \mathrm{D}$ values for estimating migratory origins. $\delta \mathrm{D}$ values of claw tips from 66 different individuals, each sampled once during the breeding season, showed an average change of $-0.3 \%$ o to $-0.4 \%$ o per day in the direction of the expected local Ontario value. There were no significant sex or species differences in the rate of change. These results suggest $\delta \mathrm{D}$ values of claw tips in Parulids may reflect those of the non-breeding area for 3-7 weeks after arrival on the breeding grounds, and are useful estimators of non-breeding migratory origin. Our results also suggest that these species may leave the breeding ground before claw tips fully incorporate a local $\delta \mathrm{D}$ signature, as claws sampled at the end of the breeding season did not match locally grown feather and claw $\delta D$ values. This is the first study to examine the seasonal rate of the change in $\delta \mathrm{D}$ values of claws in long-distance, insectivorous, migratory birds.
\end{abstract}

RÉSUMÉ. Le déclin généralisé de plusieurs espèces d'oiseaux migrateurs a attiré l'attention sur l'ampleur de la connectivité migratoire entre les populations reproductrices et hivernantes. L'analyse des isotopes stables d'hydrogène $(\delta \mathrm{D})$ de plumes est une technique utile pour mesurer la connectivité, mais elle est régie par les caractéristiques de la mue (localisation et moment). Les griffes sont des tissus kératineux inertes sur le plan métabolique; elles croissent continuellement et peuvent être prélevées n'importe quand durant l'année, fournissant ainsi des indices potentiellement intéressants sur les déplacements antérieurs d'un individu. Toutefois, les variations dans le taux d'intégration des valeurs locales de $\delta \mathrm{D}$ dans les griffes ne sont pas bien documentées. Nous avons mesuré la valeur de $\delta \mathrm{D}$ de griffes de deux espèces de parulines migratrices néotropicales-néarctiques (Paruline à ailes dorées et Paruline azurée) se reproduisant dans l'Est de l'Ontario, Canada, afin d'étudier la variation de cette valeur au cours de la saison de reproduction et de connaitre son utilité pour évaluer l'origine migratoire. La valeur de $\delta \mathrm{D}$ de l'extrémité de griffes de 66 individus, chacun échantillonné une fois pendant la saison de reproduction, a montré une variation moyenne de $-0.3 \%$ à $-0.4 \%$ par jour, en accord avec à la valeur locale attendue pour l'Ontario. Il n'y a pas eu de différences significatives dans la variation de la valeur de $\delta \mathrm{D}$ selon le sexe ou l'espèce. Ces résultats indiquent que les valeurs de $\delta \mathrm{D}$ de l'extrémité de griffes de parulines sur les aires de reproduction peuvent

${ }^{1}$ Department of Biology, Queen's University, ${ }^{2}$ Department of Biology,
University of New Brunswick, ${ }^{3}$ Dept of Geological Sciences and
Engineering, Queen's University

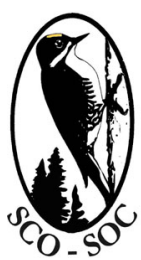

Sponsored by the Society of Canadian Ornithologists and Bird Studies Canada

Parrainée par la Société des ornithologistes du Canada et Études d'oiseaux Canada

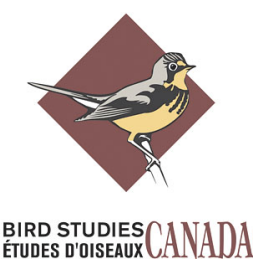


refléter les valeurs acquises en dehors de la période de reproduction, et ce, jusqu'à trois à sept semaines suivant l'arrivée sur les aires de reproduction. Ces valeurs de $\delta \mathrm{D}$ représentent donc un estimateur utile de leur origine migratoire avant la reproduction. Nos résultats laissent aussi croire que ces espèces quittent peut-être les aires de reproduction avant que l'extrémité des griffes n'incorpore pleinement une signature locale de $\delta \mathrm{D}$, puisque la valeur de $\delta \mathrm{D}$ des griffes échantillonnées à la fin de la saison de reproduction ne correspondait pas à la valeur de $\delta \mathrm{D}$ des plumes et des griffes qui avaient poussé localement. Cette étude est la première à examiner la variation saisonnière de la valeur de $\delta \mathrm{D}$ des griffes d'oiseaux migrateurs de longue distance qui sont insectivores.

Key Words: Avian claw; conservation; migratory connectivity; Neotropical-Nearctic migrants; stablehydrogen isotopes

\section{INTRODUCTION}

Migratory connectivity is the degree to which local populations of breeding individuals share a nonbreeding area and vice versa (Webster et al. 2002), and is important for understanding the population dynamics and conservation of many migratory animals (Norris et al. 2006). Long-distance tracking of passerine birds that winter in the Neotropics and breed at temperate latitudes is challenging because of their small size and lengthy migration. Stableisotope analysis of avian tissues can provide useful information for drawing inferences about avian movement and geographical links within and between breeding and non-breeding regions (Hobson 2005).

Most stable-isotope studies of long-distance movements of Neotropical-Nearctic passerines have used feathers (Kelly et al. 2002, Rubenstein et al. 2002, Hobson et al. 2004), which are easy to sample non-invasively, and contain a permanent hydrogen isotope signature $(\delta \mathrm{D})$ that corresponds to latitude of origin (Hobson and Wassenaar 1997). However, feathers may not always be an appropriate tissue because molt must occur at a time or locale that is of interest to the researcher (Bearhop et al. 2003), and the details of molting patterns are often unknown (Pyle 1997). For example, the Goldenwinged Warbler (Vermivora chrysoptera), like many Parulids, does not engage in a pre-alternate (winter) molt (Froehlich et al. 2005), so feather keratin cannot be used for the assignment of wintering origins. Furthermore, recent studies have found considerable variation in $\delta \mathrm{D}$ values of feathers grown at a similar locale (Wunder et al. 2005, Rocque et al. 2006, but see Langin et al. 2007), suggesting this tissue may not always reflect expected local $\delta \mathrm{D}$ precipitation $\left(\delta \mathrm{D}_{\mathrm{p}}\right)$ values.
A complementary tissue to feathers for tracing migration pathways with hydrogen isotopes is claw keratin. Unlike feathers, claws grow continuously and may be sampled at any time during the annual cycle. Depending on differences in the rate of claw growth of a species, tip samples may capture signatures representing diet from the preceding few weeks (Mazerolle and Hobson 2005) to several months (Bearhop et al. 2003). Bearhop et al. (2003) scored claws of five palearctic passerines at the nail bed and then recaptured them to measure growth; they estimated the rate of growth to be $0.04 \pm 0.01$ $\mathrm{mm} /$ day, and suggested that claws could be reliable long-term position indicators. In contrast, Mazerolle and Hobson (2005) found evidence for considerable claw growth during both spring and fall migration in White-throated Sparrows (Zonotrichia albicollis) and cautioned against the use of claws for determining migratory origins. They suggested the foraging behavior of this species, which involves aggressive scratching in leaf litter, may contribute to increased claw wear and faster growth, thus greater $\delta \mathrm{D}$ change than may be found in other species. Therefore, further comparisons with other species are needed to determine the utility of claw keratin for inferring migratory connectivity.

The time scale that is represented by various portions of the claw also requires further study. Remarkably, little is known about avian claw growth, but it is hypothesized that material is deposited from both the nail bed and a thin finger of pulp running down the center of the claw, such that claw tips are expected to contain the oldest material (Bearhop et al. 2003). This was confirmed by Mazerolle and Hobson (2005), who found that claw tips of White-throated Sparrows captured on migration more closely reflected $\delta \mathrm{D}$ values of the 
wintering range than did the claw base. However, the rate at which claw tips incorporate local $\delta \mathrm{D}$ values or the time frame represented by this portion of claw had not been examined.

In this study, we measured the rate of hydrogen isotope change in claw keratin $\left(\delta D_{k}\right)$ of two Neotropical-Nearctic migrant species, Goldenwinged and Cerulean Warblers (Dendroica cerulea), collected from different individuals throughout the breeding season in eastern Ontario, Canada. These two species are among the fastest declining Neotropical-Nearctic migrants (Sauer et al. 2005). We asked whether birds arriving to the breeding ground have claw tips with values representative of the non-breeding ground, and how long it takes for these to incorporate locally expected breeding-ground values. Our goal was to estimate the time frame within which claws sampled on the breeding ground accurately represent non-breeding origins in these species.

We compared the sexes to see if potential differences in diet, rates of claw growth, or nonbreeding locations had an effect on the rate of $\delta \mathrm{D}_{k}$ change. Similarly, we compared the rate of $\delta \mathrm{D}_{\mathrm{k}}$ change in both Golden-winged and Cerulean Warblers to determine potential species differences. Individuals from a similar guild and locale with some potential overlap in habitat and prey should exhibit similar rates of claw growth and incorporation of stable-hydrogen isotopes. We also examined Golden-winged Warbler claws collected near the end of the breeding season, when individuals had been at the site for 8-10 weeks, to look for correspondence with locally grown adult feathers and claws of recent fledglings.

\section{METHODS}

A total of 42 adult Golden-winged (female $=17$, male $=25)$ and 22 Cerulean $($ female $=6$, male $=16$ ) Warblers were captured in mist nets throughout the breeding season (May-July) at the Queen's University Biological Station (QUBS, 44 $34^{\circ} \mathrm{N}, 76^{\circ}$ $19^{\prime} \mathrm{W}$ ) near Chaffey's Locks, Ontario in 2005 . In 2004, we sampled claws from three Golden-winged Warbler hatch-year individuals that had recently fledged and ten adults late in the breeding cycle (110 July), as well as the rectrices of eight adults known to have bred at the study site in the previous year. Males were captured using conspecific song playback; females via Black-capped Chickadee
(Poecile atricapillus) 'mobbing' call, or when flushed from the nest after $4 \mathrm{~d}$ of incubation. Approximately $2 \mathrm{~mm}$ of claw tip from the middle toe of both feet was collected using sharp dissection scissors, and deposited in a small paper envelope. Capture and sampling were carried out under permit from Environment Canada (CA 0106) and our field methods were approved by Queen's University Animal Care Committee (Protocol-2005-017-R1). All individuals were released without injury, and no females abandoned their nests after capture.

One claw per individual (from left or right foot, chosen randomly) was washed to remove lipids and particles in a 2:1 chloroform:methanol solution for $24 \mathrm{~h}$ and left to air dry. To account for potential exchangeable hydrogen effects between ambient laboratory water vapor and tissue, we used an equilibration technique. Claws were stored in open containers in a fume hood for at least 1 week at the Queen's Facility for Stable Isotope Research (QFIR). Although other laboratories recommend the use of a calibration curve derived for each run using three in-house keratin standards for which an estimate of the non-exchangeable $\delta \mathrm{D}$ has been derived (Wassenaar and Hobson 2003), we used a single homogenized chicken feather keratin standard $(\delta \mathrm{D}=-95 \pm 5 \%$ ) and two mineral standards (Georgia clay $\delta \mathrm{D}=-58 \%$ and brucite $\delta \mathrm{D}=-96 \%$ ). Additionally, we assumed that ambient lab moisture $\delta \mathrm{D}$ available for exchange with our standards and unknowns remained constant throughout the year as our lab was maintained at a constant temperature, and air-conditioning water came from Lake Ontario, a large reservoir with relatively constant $\delta D$. Our laboratory results for feathers and claws are assumed to be reproducible to $\pm 3 \%$, but may not be comparable to those produced by other laboratories using different calibration techniques (Wassenaar and Hobson 2006).

Mineral and keratin standards and claw samples were weighed $(0.08-0.22 \mathrm{mg})$, placed in silver capsules, and oven dried for $24 \mathrm{~h}$ at $100^{\circ} \mathrm{C}$ to remove any absorbed water, which can be a substantial source of exchangeable hydrogen (Algie and Watt 1962, Bowen et al. 2005a). Samples were crushed and loaded into an autosampler connected to a Finnigan TC/EA $\left(1450^{\circ} \mathrm{C}\right)$ reduction furnace, where they passed online to a Finnigan MAT Delta Plus XL isotope ratio mass spectrometer for analysis. Stable hydrogen isotope ratios $\left({ }^{2} \mathrm{H} /{ }^{1} \mathrm{H}=\right.$ $\mathrm{R})$ are expressed in per mil (\%o) units, where $\delta=$ $\left[\left(\mathrm{R}_{\text {sample }} / \mathrm{R}_{\text {standard }}\right)-1\right] \times 1000$ and $\mathrm{R}_{\text {standard }}$ is the 
hydrogen isotope ratio of Vienna Standard Mean Ocean Water (VSMOW).

Potential effects of source non-linearity were compensated for by analysis of the effect of $\mathrm{H} 3$ and by varying the amounts of standards and duplicate samples. Non-linearity is constantly monitored at QFIR by varying the amount of standards and by calibrating to the international standards, VSMOW and Vienna Standard Light Antarctic Precipitation (VSLAP). All standards and samples were treated in the same way, and values are reproducible to $\pm 3 \%$ o.

Statistical analyses were performed using JMP (version 5.1, SAS Institute Inc.) and R (version 2.3.1, the R Foundation for Statistical Computing). The distribution of $\delta \mathrm{D}$ claw values did not differ significantly from a normal distribution (ShapiroWilks W test, $P>0.05)$. $\delta \mathrm{D}_{\mathrm{k}}$ values were compared using independent sample $t$-tests and linear regression.

\section{RESULTS}

The relationship between Ontario $\delta \mathrm{D}_{\mathrm{k}}$ claw signatures of Golden-winged Warblers and ordinal date was highly significant (females, $n=17, \mathrm{r}^{2}=$ $0.79, P<0.0001$; males, $n=25, \mathrm{r}^{2}=0.43, P<0.0005$ ) (Fig. 1a,b). There was no significant difference in the rate of daily $\delta \mathrm{D}_{\mathrm{k}}$ change between the sexes $(P$ $=0.37)$, so the data were pooled $\left(n=42, \mathrm{r}^{2}=0.43\right.$, $P<0.0001$ ) (Fig. 1c). The $\delta \mathrm{D}_{\mathrm{k}}$ rate of change in claws per day was $-0.4 \%$ (Fig. 1c) in the direction of a $\delta \mathrm{D}_{\mathrm{k}}$ signature $(-81 \%$ ) expected in Ontario. Arrival signatures fell within the range of expected $\delta \mathrm{D}_{\mathrm{k}}$ values $(-24 \% o<\mathrm{x}>-89 \%$ ) for the non-breeding locales in Central America and northern South America. Expected $\delta D_{k}$ values for breeding and non-breeding locales were calculated using interpolated, growing season averages compiled by the International Atomic Energy Association (IAEA 2001) and a discrimination factor of $-19 \%$ o for keratin (Bowen et al. 2005b).

The relationship between Ontario $\delta \mathrm{D}_{\mathrm{k}}$ values for claws from Cerulean Warblers (females $n=6$, males $n=16$ ) and ordinal date was also highly significant $\left(\mathrm{r}^{2}=0.64, P<0.0001\right)$ (Fig. 2). The rate of change in the $\delta \mathrm{D}_{\mathrm{k}}$ values of claws per day was $-0.4 \%$ in the direction of an Ontario $\delta \mathrm{D}_{\mathrm{k}}$ signature.
There was no significant difference in the rate of daily change in the $\delta \mathrm{D}_{\mathrm{k}}$ values between species $(P$ $=0.17)$. At this rate, for both species, it would take approximately 16-17 weeks from arrival on the breeding ground for claw tips to reflect a local $\delta \mathrm{D}$ signature.

The $\delta \mathrm{D}_{\mathrm{k}}$ values of adult Golden-winged Warbler claws $(n=10)$ collected near the end of the breeding season (1-10 July) were significantly less negative than both adult retrices $(n=8$, independent values $t$-test, $\left.t_{15}=2.1, P<0.0001\right)$ and fledgling claws $(n$ $=3$, independent values $t$-test, $t_{10}=2.2, P<0.0001$ ) grown at the study site (Fig. 3 ).

\section{DISCUSSION}

The significant relationship between $\delta \mathrm{D}_{\mathrm{k}}$ values and time (Figs. 1 and 2) shows that individuals begin to incorporate local hydrogen isotopes in claw tissue upon arrival at the breeding ground. The gradual, steady change in claw tip signature through the season must be due to effects of new growth, confirming Bearhop's (2003) characterization that layers are deposited continually from within the claw, eventually moving outward to the claw tip. Using the slope as an indicator of change in $\delta D_{k}$ values, we found rates of $-0.4 \%$ o per day for both Golden-winged and Cerulean Warblers in the direction of local $\delta \mathrm{D}(-81 \%$ ) values (Figs. 1, 2). These results also reinforce the notion that claws, unlike feathers, are a dynamic tissue that continually incorporates hydrogen isotopes from local meteoric sources.

We did not find any sex differences in rates of change in $\delta D_{k}$ values in claws of Golden-winged Warblers (Fig. 1) nor, as predicted, any species difference between Golden-winged and Cerulean Warblers. Both species glean similar insect prey from leaves and leaf clusters (Confer 1992, Hamel 2000) and would likely experience similar degrees of claw wear, contributing to shared $\delta \mathrm{D}_{\mathrm{k}}$ values.

In both previous studies of claw keratin, rates of stable hydrogen change were estimated either by external scoring techniques (Bearhop et al. 2003) or through comparisons between $\delta \mathrm{D}_{\mathrm{k}}$ values of claws collected on migration and expected $\delta \mathrm{D}_{\mathrm{k}}$ values for wintering locales (Mazerolle and Hobson 2005). In this study, in order to minimize our impacts on the 
Fig. 1. The relationship between $\delta \mathrm{D}_{\mathrm{k}}$ values of Ontario Golden-winged Warbler claws (a-c; females $n=$ 17 , males $n=25$ ) and ordinal date shows a $0.4 \%$ per day shift toward locally expected values. The solid line represents a least-squared linear regression.

\section{a) GWWA Females}

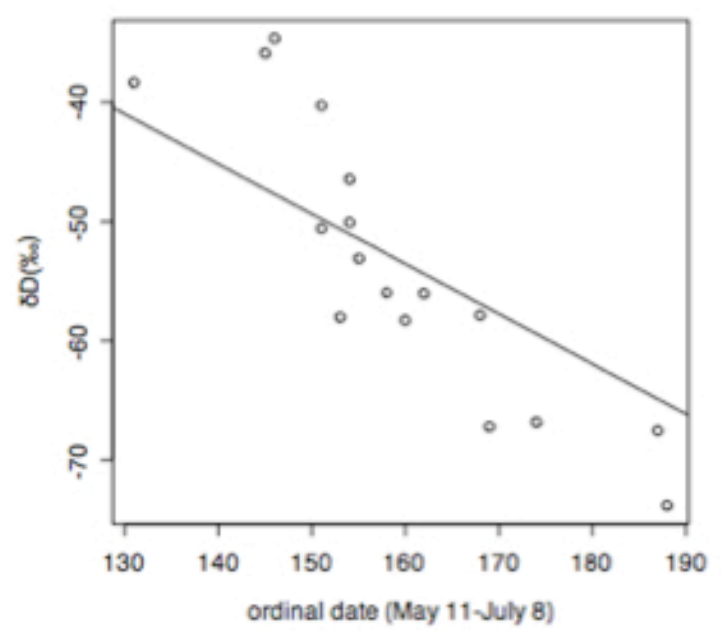

c) GWWA Females and Males b) GWWA Males

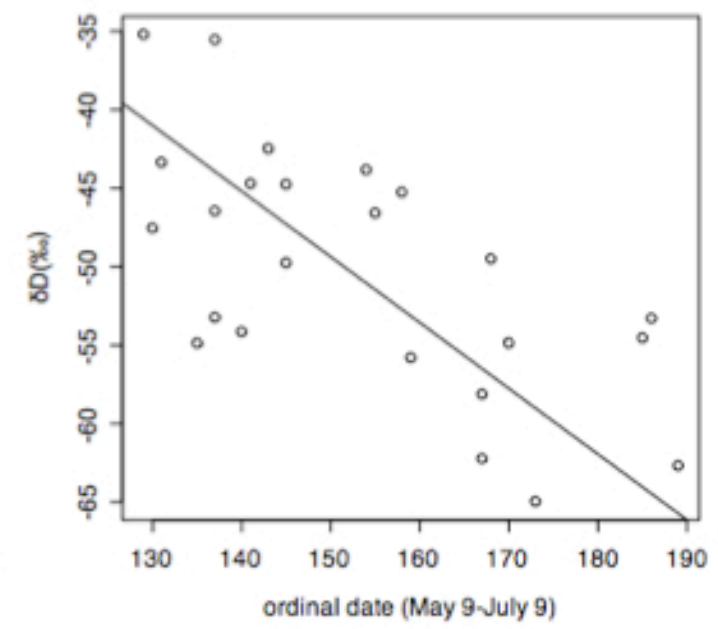

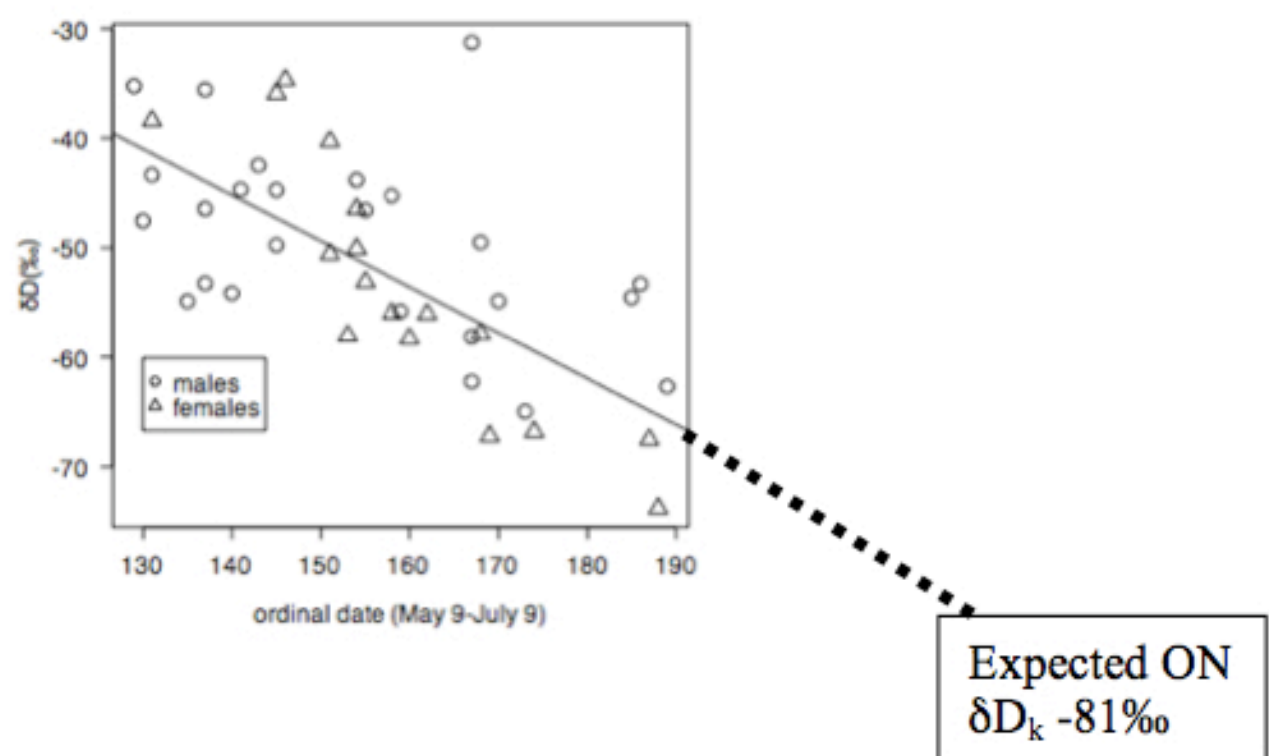


Fig. 2. The relationship between $\delta D_{k}$ values in claws of Cerulean Warblers collected in Ontario (females $n=6$, males $n=16$ ) and ordinal date. There was no significant difference between the rate of $\delta \mathrm{Dk}$ change for breeding Golden-winged and Cerulean Warblers. The solid line represents a least-squared linear regression.

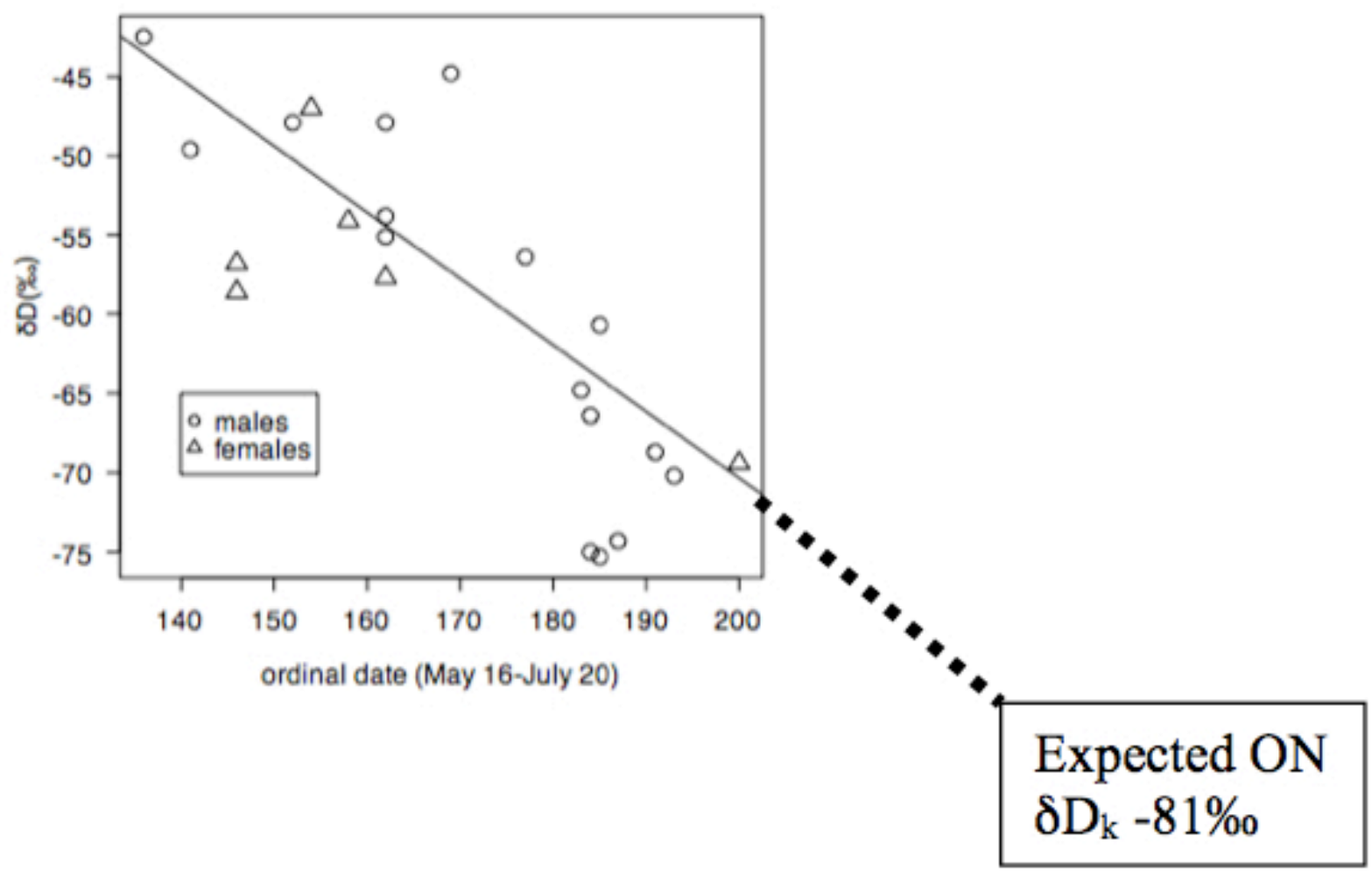

breeding success of these declining species (COSEWIC 2006), we chose not to recapture individuals to measure claw growth directly to estimate stable hydrogen change. However, by sampling changes in $\delta \mathrm{D}_{\mathrm{k}}$ values of claw tips over the entire breeding season, our estimation of rates of change in claw keratin values improves the resolution of previous estimates. These results suggest claw tips in Parulids may reflect $\delta D_{p}$ values of the non-breeding range for approximately 3-7 weeks after arrival at the breeding grounds, and are thus useful indicators of winter migratory origin. The rate of change through the breeding season may also be used to calculate backward from later captures, so that $\delta \mathrm{D}_{\mathrm{k}}$ values at arrival can be ascertained.
The ability to pinpoint specific origins for Neotropical-Nearctic migrants is limited by the current width at which researchers may confidently delineate $\delta \mathrm{D}_{\mathrm{p}}$ isoscapes across the non-breeding ranges for many species. The current size of $\delta D_{p}$ isoscapes in the Neotropics is quite broad at $\sim 20-$ $30 \%$ (IAEA 2001). Future efforts to characterize geographic variation in $\delta \mathrm{D}$ values across the nonbreeding range in both precipitation and claw keratin will greatly improve our abilities to determine migratory connectivity patterns (Hobson 2005), as will investigation into potential intraseasonal latitudinal or altitudinal movements within the Neotropics by migrants in the non-breeding period. 
Fig. 3. $\delta D_{k}$ values of breeding Golden-winged Warbler adult tail retrices $(n=8)$ and recent fledgling claws $(n=3)$ compared with $\delta \mathrm{D}_{\mathrm{k}}$ values of claws $(n=10)$ collected near the end of the breeding season (1-10 July 2005). Tail feathers and claws grown in Ontario reflect locally expected values. Claws collected at the end of the breeding season in Ontario do not yet reflect local values.

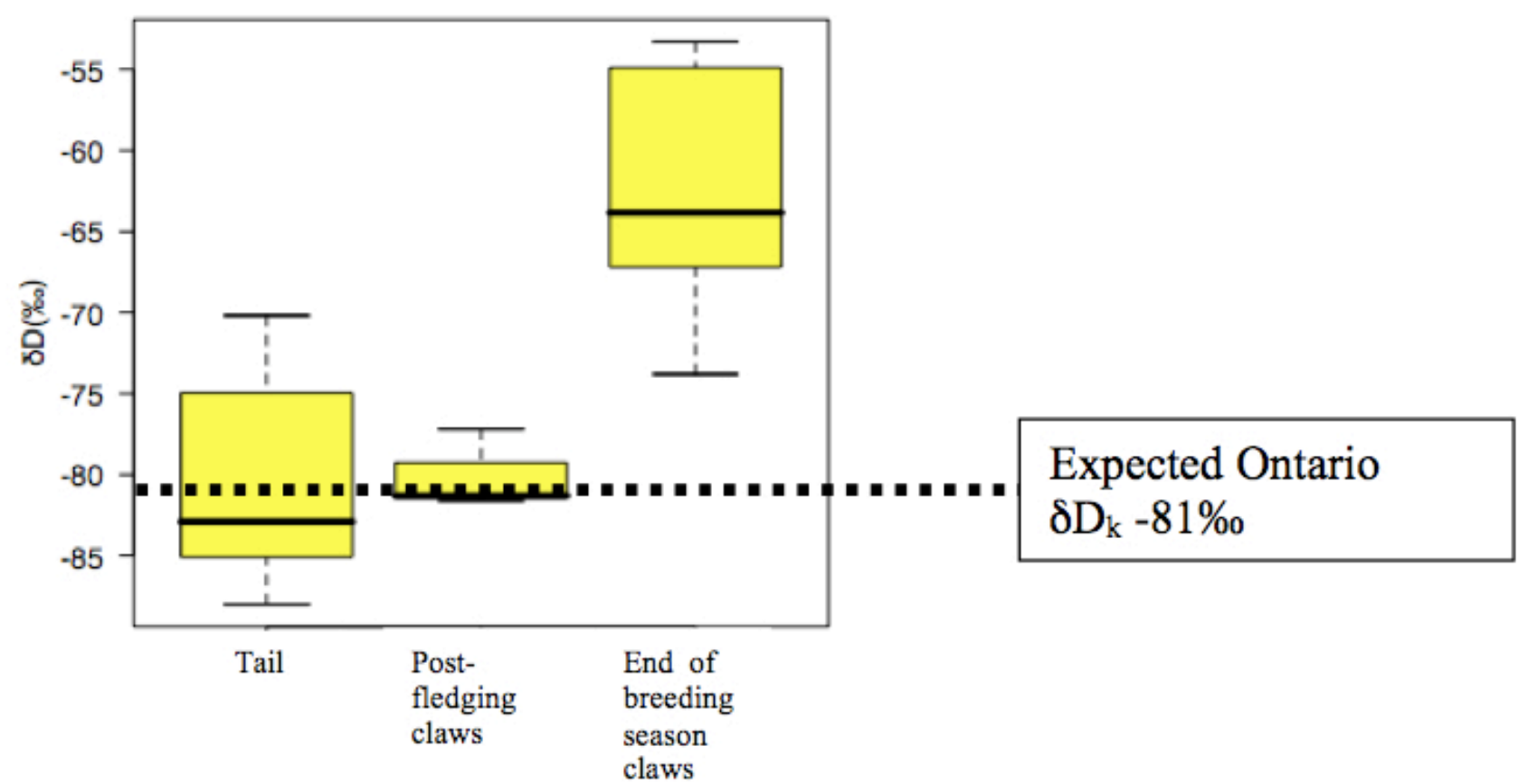

Currently, little is known about the duration of migration in Parulidae. It is thought that the spring migratory period is approximately a month in duration for wood-warblers (Marra et al. 2005). Using our rate of change in $\delta \mathrm{D}_{\mathrm{k}}$ values, this would represent a maximum of $-12 \%$ change over the course of migration. As suggested, this falls well within the resolution with which we may infer wintering origins, and represents a smaller change than was found for the ground-foraging Whitethroated Sparrow (Mazerolle and Hobson 2005). However, we calculated changes in $\delta \mathrm{D}_{\mathrm{k}}$ values assuming a similar rate of change for both migratory and breeding periods, and it is possible, although unlikely, that these rates may differ. Further work is needed to determine if the rate of change in $\delta \mathrm{D}$ values is similar for other periods of the annual cycle.
We may have less success with the use of adult claws for inferring breeding origins in Ontario from samples collected on the non-breeding range. First, our results suggest breeding warblers may never attain local claw signatures. If $\delta D_{k}$ values are incorporated at an average rate of $-0.4 \%$ o per day, it would take approximately 16 weeks for claw tips of breeding birds to represent local $\delta \mathrm{D}_{\mathrm{p}}$, which is longer than the breeding season of either species, but is less than the non-breeding season. Indeed, Golden-winged Warblers sampled in the final stages of the breeding cycle did not yet reflect local $\delta D_{p}$ values (Fig. 3). Similarly, Bearhop et al. (2005) found that the $\delta D_{k}$ claw values of European Blackcaps (Sylvia atricapilla) collected near the end of the non-breeding season differed significantly from those of resident birds, which suggests that the temporal period required for claw tissue to reflect 
local values exceeded the time of residence in this species.

\section{CONCLUSION}

We found that: $\delta \mathrm{D}_{\mathrm{k}}$ claw values changed at an average rate of $-0.3 \%$ to $-0.4 \%$ o per day in the direction of expected local values during the breeding season; there were no significant species or sex differences in this rate; and values of claw tips in Parulids may reflect those of the nonbreeding ground for 3-7 weeks after arrival, making them useful estimators of non-breeding migratory origin. Further work aimed at characterizing isotopic values of avian claw material could greatly improve the use of this medium in migratory connectivity studies. The time period required for claws to incorporate local hydrogen isotope values may be similar for other elements $\left(\delta^{15} \mathrm{~N}, \delta^{13} \mathrm{C}\right)$, but more work is needed. As improved $\delta \mathrm{D}_{\mathrm{p}}$ and $\delta \mathrm{D}_{\mathrm{k}}$ maps become available for the Neotropics, the need to delineate the rate of isotopic change in claws with greater precision becomes more critical. Analysis of the individual keratin layers deposited within the claw (akin to the rings of a tree) may allow us to examine migratory movements as well as shifts in habitat and diet on a finer scale.

Responses to this article can be read online at: http://www.ace-eco.org/vol3/iss 1/art2/responses/

\section{Acknowledgments:}

Funding for this project was provided by an Ontario Graduate Scholarship and Queen's Graduate Award (Kevin Fraser), the Canada Foundation for Innovation/Ontario Innovation Trust (T. Kurt Kyser), and NSERC Discovery and MFA grants (T. Kurt Kyser, Laurene Ratcliffe, Raleigh Robertson). We would like to thank Kerry Klassen and April Vuletich at the Queen's Facility for Isotope Research (QFIR), the support staff at the Queen's University Biology Station (QUBS), Rachel Vallender, Sherilee Harper, Emily McKinnon, and Anna Yunnie for field assistance, and Katie Geale for help in the lab. We thank Keith Hobson and two anonymous reviewers for their helpful comments on this manuscript.

\section{LITERATURE CITED}

Algie, J. E., and I. C. Watt. 1962. Stabilization of keratin structure by incorporated water, estimation of aliphatic nitro compounds. Nature 193:972-973.

Bearhop, S., W. Fiedler, R. W. Furness, S. C. Votier, S. Waldron, J. Newton, G. J. Bowen, P. Berthold, and K. Farnsworth. 2005. Assortative mating as a mechanism for rapid evolution of a migratory divide. Science 310:502-504.

Bearhop, S., R. W. Furness, G. C. Hilton, S. C. Votier, and S. Waldron. 2003. A forensic approach to understanding diet and habitat use from stable isotope analysis of (avian) claw material. Functional Ecology 17:270-275.

Bowen, G. J., L. Chesson, K. Nielson, T. E. Cerling, and J. R. Ehleringer. 2005a. Treatment methods for the determination of $\delta^{2} \mathrm{H}$ and $\delta^{18} \mathrm{O}$ of hair keratin by continuous-flow isotope-ratio mass spectrometry. Rapid Communications in Mass Spectrometry 19:2371-2378.

Bowen, G. J., L. I. Wassenaar, and K. A. Hobson. $2005 \mathrm{~b}$. Global application of stable hydrogen and oxygen isotopes to wildlife forensics. Oecologia 143:337-348.

Confer, J. L. 1992. Golden-winged Warbler (Vermivora chrysoptera). Number 20 in A. Poole, P. Stettenheim, and F. Gill, editors. The birds of North America. Academy of Natural Sciences, Philadelphia, Pennsylvania, USA and American Ornithologists' Union, Washington, D.C., USA. [online] URL: http://bna.birds.cornell.edu/BNA/.

COSEWIC. 2006. Canadian Species at Risk, May 2006. Committee of the Status of Endangered Wildlife in Canada, Ottawa, ON.

Froehlich, D. R., S. Rohwer, and B. J. Stutchbury. 2005. Spring molt constraints versus winter territoriality. Pages 321-335 in R. Greenberg and P. P. Marra, editors. Birds of two worlds: the ecology and evolution of migration. Johns Hopkins University, Baltimore, Maryland, USA.

Hamel, P. B. 2000. Cerulean Warbler (Dendroica cerulea). Number 511 in A. Poole, P. Stettenheim, and F. Gill, editors. The birds of North America. Academy of Natural Sciences, Philadelphia, Pennsylvania, USA and American Ornithologists' 
Union, Washington, D.C., USA. [online] URL: htt p://bna.birds.cornell.edu/BNA/.

Hobson, K. A. 2005. Stable isotopes and the determination of avian migratory connectivity and seasonal interactions. The Auk 122:1037-1048.

Hobson, K. A., Y. Aubry, and L. I. Wassenaar. 2004. Migratory connectivity in Bicknell's Thrush: locating missing populations with hydrogen isotopes. Condor 106:905-909.

Hobson, K. A., and L. I. Wassenaar. 1997. Linking breeding and wintering grounds of NeotropicalNearctic migrant songbirds using stable hydrogen isotopic analysis of feathers. Oecologia 109:142148.

International Atomic Energy Association (IAEA). 2001. Global network for isotopes in precipitation, the GNIP database. [online] URL: http://isohis.iaea.org.

Kelly, J. F., V. Atudoreli, Z. C., Sharp, and D. M. Finch. 2002. Insights into Wilson's Warbler migration from analyses of hydrogen stable isotope ratios. Oecologia 130:216-221.

Langin, K. M., M. W. Reudink, P. P. Marra, D. R. Norris, K. K., Kyser, and L. M. Ratcliffe. 2007. Hydrogen isotopic variation in migratory bird tissues of known origin: implications for geographic assignment. Oecologia 152:449-457.

Marra, P. P., C. M. Francis, R. S. Mulvhill, and F. R. Moore. 2005. The influence of climate on the timing and rate of spring bird migration. Oecologia 141:307-315.

Mazerolle, D. F., and K. A. Hobson. 2005. Estimating origins of short-distance migrant songbirds in North America: contrasting inferences from hydrogen isotope measurements of feathers, claws, and blood. The Condor 107:280-288.

Norris, D. R., P. P. Marra, T. K. Kyser, J.A. Royle, G. J. Bowen, and L. M. Ratcliffe. 2006. Migratory connectivity of a widely distributed NeotropicalNearctic migratory songbird. Ornithological Monographs 61:14-28.

Pyle, P. 1997. Identification guide to North American birds. Part 1 Columbidae to Ploceidae. Slate Creek Press, Bolinas, California, USA.
Rocque, D. A., M. Ben-David, R. P. Barry, and K. Winker. 2006. Assigning birds to wintering and breeding grounds using stable isotopes: lessons from two feather generations among three intercontinental migrants. Oecologia 147:395-404.

Rubenstein, D. R., C. P. Chamberlain, R. T. Holmes, M. P. Ayres, J. R. Waldbauer, G. R. Graves, and N. C. Tuross. 2002. Linking breeding and wintering ranges of a migratory songbird using stable isotopes. Science 295:1062-1065.

Sauer, J. R., J. E. Hines, and J. Fallon. 2005. The North American breeding bird survey, results and analysis 1966-2004. Version 2005.2. USGS Patuxent Wildlife Research Center, Laurel, Maryland, USA. [online] URL: http://www.mbr-pw rc.usgs.gov/bbs/bbs2004.html.

Wassenaar, L. I., and K. A. Hobson. 2003. Comparative equilibration and online technique for determination of non-exchangeable hydrogen of keratins for use in animal migration studies. Isotopes in Environmental and Health Studies 39:17.

Wassenaar, L. I., and K. A. Hobson. 2006. Stablehydrogen isotope heterogeneity in keratinous materials: mass spectrometry and migratory wildlife tissue sampling strategies. Rapid Communications in Mass Spectrometry 20:1-6.

Webster, M. S., P. P. Marra, S. M. Haig, S. Bensch, and R. T. Holmes. 2002. Links between worlds: unraveling migratory connectivity. TRENDS in Ecology and Evolution 17:76-83.

Wunder, M. B., C. L. Kester, F. L. Knopf, and R. O. Rye. 2005. A test of geographic assignment using isotope tracers in feathers of known origin. Oecologia 144: 607-617. 